\title{
The genome profiling method can be applied for species identification of biological materials collected at crime scenes
}

\author{
Takako Kinebuchi, Nozomi Idota, Hajime Tsuboi, Marin Takaso, Risa Bando and Hiroshi Ikegaya (10)
}

\begin{abstract}
Background: Various biological materials unrelated to humans are found at crime scenes and it is often important to elucidate the origin of these materials. A genetic locus common to several species is conventionally PCRamplified with universal primers to identify species. However, not all species can be identified using a single locus. In this study, DNA from 13 commonly handled taxa was analyzed to identify species by a genome profiling (GP) method, which involves random PCR and temperature gradient gel electrophoresis.

Results: In a clustering analysis, we successfully obtained a single cluster for each species.

Conclusion: The GP method is cost-effective and does not require advanced techniques and knowledge in molecular biology. The random sampling of the whole genome using multiple primers provides substantial genomic information. Therefore, the method is effective for classifying a wide range of species, including animals, plants, and insects, and is useful for crime scene investigations.
\end{abstract}

Keywords: Forensic science, Genome profiling, Species identification, Detection, Classification, Random primers

\section{Background}

Several methods to detect human-specific DNA have been developed to identify victims or suspects, using biological materials such as blood stains, hair, small tissue particles, and body fluids found at crime scenes [1-3]. It is important to identify materials derived from humans; however, for materials that are not of human origin, it is often still important to determine the source. For instance, this can be important in cases where feces are placed in front of a house, when hair or bone fragments are mixed in a food manufacturing factory, or when wild animals cause agricultural damage. Species identification from biological materials found at a crime scene can inform subsequent police investigations.

For non-human biological materials, such as meat pieces, blood, hair, and bone fragments, the amplification

\footnotetext{
* Correspondence: ikegaya-tky@umin.ac.jp

Department of Forensic Medicine, Graduate School of Medical Science, Kyoto Prefectural University of Medicine, 465 Kajiicho, Kamigyo, Kyoto 602-8566, Japan
}

of a species-specific locus by PCR is commonly performed [4-8]. However, only expected creatures can be investigated using this approach. There are many methods for amplifying sequences common to multiple species using universal primers, such as the amplification of mitochondrial rDNA [9, 10], cytochrome b [11, 12], cytochrome oxidase I [13, 14], myoglobin [15], or the D-loop region [16-20] and subsequent identification using the Basic Local Alignment Search Tool. Even if sequences for many species are registered in the database, the location of the sequence varies. Accordingly, there is a limit to species identification based on a single locus. In addition, even if samples belong to the same species, there may be individual differences in DNA sequences. To address these issues, analyses of additional loci and molecular phylogenetic approaches are needed. However, these methods are relatively expensive and require expertise and equipment.

In this study, we focused on the genome profiling (GP) method. The GP method was developed by Nishigaki et al. in the bioindustry field in 1971 [21]. In the GP 
method, DNA is PCR-amplified using random primers (random PCR) and temperature gradient gel electrophoresis (TGGE) is performed. Depending on the number of amplified fragments and the melting temperatures of the double-stranded DNA, species identification dots (spiddos) are obtained on the temperature gradient gel. These spiddos are corrected using internal standards. Then, the spiddos pattern is compared between samples and references and a pattern similarity score (PaSS) is obtained. Using this PaSS, a cluster analysis is performed to identify species.

This method corresponds to random sampling in statistics. It is possible to analyze information for the entire genome at a very low cost in a short period of time, without requiring any special knowledge or techniques. Using this GP method, we have identified human body fluid [22, 23] and viral species [24] and differentiated between humans and other mammalian species [25].

The GP method is highly sensitive and accordingly it can potentially be used like the Ames test for mutagen analyses [26]. Additionally, the potential for personal identification in humans has also been reported [27]. In this study, we selected a wide range of target organisms, including common fish, birds, and various mammals, and examined whether it is possible to identify these organisms using the GP method.

\section{Results}

Four or more spiddos were obtained for all samples, regardless of species (Table 1). The average number of spiddos obtained from each sample was $11.7 \pm 3.1$ (range 5-21) for SP-1, $12.7 \pm 3.8$ (range 5-22) for SP-2, and $7.0 \pm 3.0$ (range 4-16) for SP-3.

Table 1 Number of spiddos in various animal species, obtained using three different random primers

\begin{tabular}{lllll}
\hline Species & SP-1 & SP-2 & SP-3 & Total \\
\hline Cattle $(n=4)$ & $9.0 \pm 2.0$ & $12.3 \pm 3.6$ & $6.5 \pm 1.0$ & $27.8 \pm 4.6$ \\
Pig $(n=4)$ & $10.5 \pm 1.3$ & $16.0 \pm 1.8$ & $6.5 \pm 2.1$ & $33.0 \pm 4.2$ \\
Sheep $(n=4)$ & $11.3 \pm 1.5$ & $9.75 \pm 3.4$ & $5.8 \pm 1.0$ & $26.8 \pm 4.3$ \\
Chicken $(n=4)$ & $14.0 \pm 4.9$ & $13.0 \pm 1.4$ & $9.0 \pm 1.2$ & $36.0 \pm 5.6$ \\
Greater amberjack $(n=4)$ & $14.8 \pm 3.6$ & $19.0 \pm 2.1$ & $6.3 \pm 1.9$ & $40.0 \pm 2.9$ \\
Bigeye tuna $(n=4)$ & $14.8 \pm 2.5$ & $12.5 \pm 1.9$ & $5.3 \pm 1.0$ & $32.5 \pm 2.4$ \\
Silver salmon $(n=4)$ & $14.8 \pm 2.2$ & $14.8 \pm 1.3$ & $6.3 \pm 1.3$ & $35.8 \pm 3.3$ \\
Horse mackerel $(n=4)$ & $10.8 \pm 0.5$ & $14.8 \pm 1.5$ & $5.3 \pm 1.9$ & $30.8 \pm 1.9$ \\
Halibut $(n=4)$ & $11.8 \pm 2.9$ & $13.0 \pm 3.3$ & $5.3 \pm 1.0$ & $30.0 \pm 4.4$ \\
Dog $(n=3)$ & $11.0 \pm 1.4$ & $12.3 \pm 1.7$ & $9.8 \pm 2.1$ & $33.0 \pm 4.1$ \\
Cat $(n=3)$ & $10.5 \pm 1.3$ & $13.3 \pm 3.3$ & $13.0 \pm 2.5$ & $36.8 \pm 5.5$ \\
Rat $(n=4)$ & $5.3 \pm 1.0$ & $4,5 \pm 1.0$ & $6.5 \pm 1.3$ & $16.3 \pm 1.5$ \\
Human $(n=3)$ & $13.3 \pm 2.1$ & $11.3 \pm 2.5$ & $6.3 \pm 1.5$ & $31.0 \pm 2.6$ \\
Total & $11.7 \pm 3.1$ & $12.7 \pm 3.8$ & $7.0 \pm 3.0$ & \\
\hline
\end{tabular}

Numbers are shown as averages \pm S.D

$n:$ number
The average numbers of spiddos obtained using SP-1 to -3 were 27.8 for cattle, 33.0 for pigs, 26.8 for sheep, 36.0 for chickens, 40 for greater amberjack, 32.5 for bigeye tuna, 35.8 for silver salmon, 30.8 for Japanese horse mackerel, 30.0 for Japanese halibut, 33.0 for dog, 36.8 for cat, 16.3 for rat, and 31.0 for human.

Phylogenetic trees were generated using PaSS values for each primer. Using the SP-1 primer, the same species were classified into a single cluster for cattle, sheep, Japanese halibut, greater amberjack, Japanese horse mackerel, and rat. However, mixed clusters were obtained for other species (Fig. 1a). Using the SP-2 primer, the same species were classified into a single cluster for cattle, pig, chicken, greater amberjack, bigeye tuna, silver salmon, Japanese horse mackerel, Japanese halibut, rat, and human. However, mixed clusters were obtained for sheep (Fig. 1b). Using the SP-3 primer, the same species were classified into a single cluster only for chicken and Japanese halibut, and the other species formed mixed clusters (Fig. 1c). Cluster formation was not related to the number of spiddos.

When a cluster analysis was performed based on average PaSS values for SP-1, SP-2, and SP-3, samples from the same species were classified into the same cluster for all species (Fig. 2).

\section{Discussion}

In the field of forensic medicine, DNA typing by short tandem repeat (STR) analysis is generally accepted for the personal identification of biological materials such as blood, semen, and saliva stains collected at a crime scene $[28,29]$. However, it is often presumed that blood stains are human in origin. First, it is important to confirm whether the material is derived from humans. For nonhuman samples, a universal method for species identification is needed.

Though there is a report that simple sequence repeat (SSR) is very effective for determining the differences among species [30], many reports using a genetic approach, including STR or other methods, determined the differences in the same species. The GP method can be used to detect all species, including humans, animals [25], insects, plants [31], bacteria [32], and fungi [33], following a single protocol. Using the GP method, results can be obtained in a few hours, including random PCR and 10 min of TGGE. The cost is only a few dollars per sample.

For the GP method, the accuracy of species determination depends on the number of spiddos obtained by random PCR. A spiddos shows not only the cleaved temperature of the double-stranded DNA fragment amplified by random PCR, but also specific DNA sequences. Therefore, analyzing spiddos is the same as performing random sampling for large-scale genome 


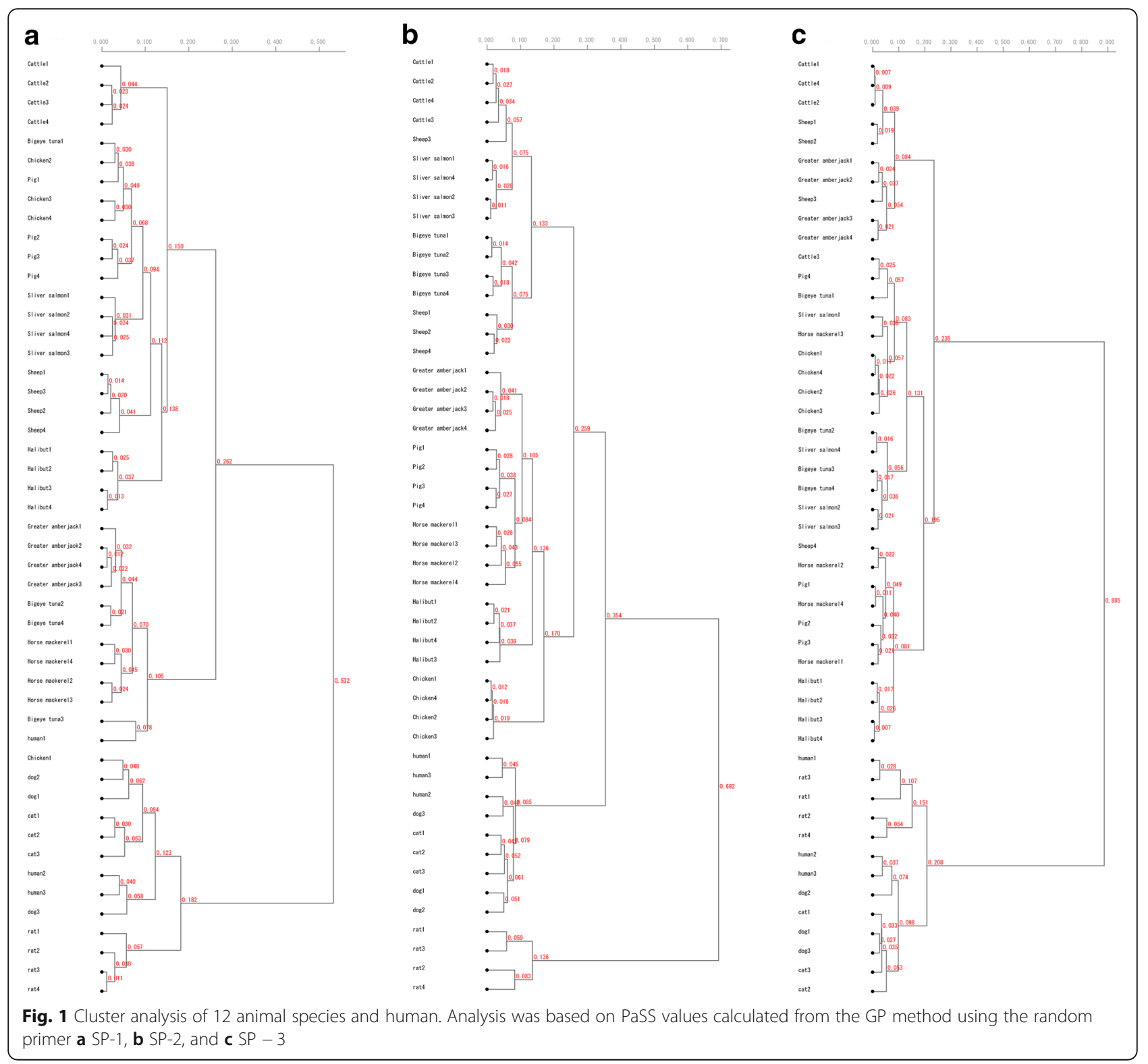

information. For this reason, primers that can amplify a larger number of spiddos are useful to maximize the genome information that is obtained.

However, there is a limit to the number of spiddos that can be obtained using a single primer. Accordingly, the number of spiddos can be increased by increasing the number of random primers, resulting in a more accurate cluster analysis [33]. In our study, we were able to classify species more accurately using the average value of the results obtained using three primers (Fig. 2) than using each of the three primers separately (Fig. 1a, b, and $\mathrm{c}$ ). By using multiple random primers, even closely related species, such as the cattle and sheep groups or the greater amberjack and horse mackerel groups, can be classified correctly. Our results indicate that species identification by the GP method using multiple random primers is very accurate.

Classification based on a very small part of the whole genome is sometimes difficult for closely related species. Moreover, the reliability of the results may be insufficient when the whole genome is not analyzed. The GP method, in which the whole genome is analyzed by random sampling, addresses these limitations and is sufficient for species classification. However, the GP method has various limitations. First, it is difficult to apply to mixed samples. Although mixed samples were not examined in this report, both genomes are expected to be randomly amplified, and it may be difficult to determine their species. In previous studies of virus detection using body fluids, we found species-specific spiddos [23, 24]. 


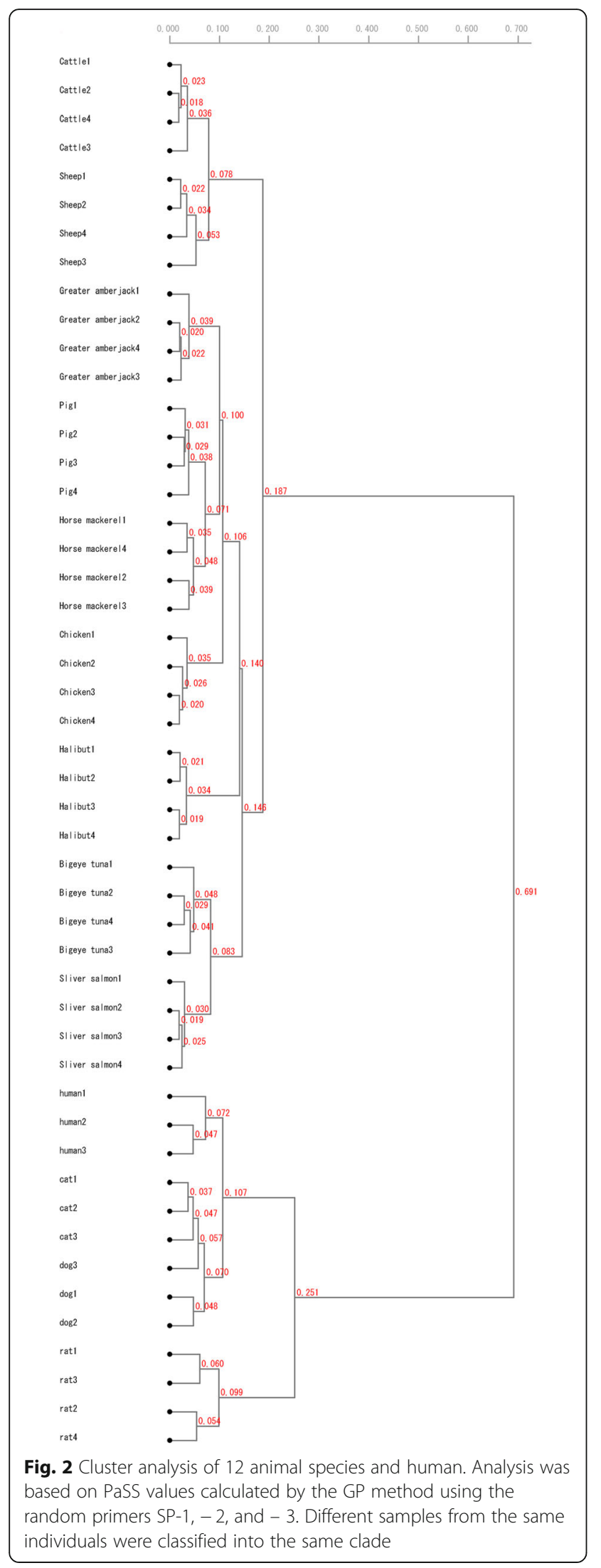

There may be specific spiddos in various species. Further studies are required to evaluate this species specificity. A second problem is related to the reference samples. Although there are international databases for DNA sequences, a database of TGGE images does not exist. Therefore, it is necessary to prepare DNA for the suspected species once to obtain images for comparison.

\section{Conclusion}

Despite the issues described above, the GP method can save time, labor, and costs, and although it is a random sampling approach, it can be used to obtain whole genome information. Therefore, the GP method is also an effective approach for classifying species and can be used for criminal investigations.

\section{Methods}

\section{Samples}

Human and 12 species that are often found in the house or household kitchens were used in this study, i.e., cattle (Bos taurus), pig (Sus scrofa domesticus), sheep (Ovis aries), chicken (Gallus Gallus domesticus), greater amberjack (Seriola dumerili), bigeye tuna (Thunnus obesus), silver salmon (Oncorhynchus kisutch), Japanese horse mackerel (Trachurus japonicus), Japanese halibut (Paralichthys olivaceus), dog (Canis lupus familiaris), cat (Felis catus), and rat (Rattus norvegicus). The meats of cattle, pig, sheep, chicken, greater amberjack, bigeye tuna, silver salmon, Japanese horse mackerel, and Japanese halibut were purchased at a grocery store in the city market. Samples were collected by scrubbing the surface of each raw meat with a cotton swab. The dog, cat, and rat samples were obtained at pet shops by scrubbing the buccal mucosa of each species with a cotton swab. Human samples were obtained from healthy adult volunteers who provided written informed consent. The buccal mucosa of each volunteer was scrubbed with a cotton swab. A total of 49 samples (3-4 samples for each animal species and 3 samples for human) were collected.

Cotton swabs were digested with Proteinase K overnight at $56^{\circ} \mathrm{C}$. DNA was extracted using QIAamp DNA Mini Kits (Qiagen, Tokyo, Japan). The DNA concentration was adjusted to $5 \mathrm{ng} / \mu \mathrm{L}$.

\section{Random PCR}

Three random primers, SP-1 (pfm12) (5'-AGAACGCGC CTG-3'), SP-2 (pfm19) (5'-CAGGGCGCGCGTAC-3'), and SP-3 (hunt) (5'-TGCTGCTGCTGC-3') were used [34]. PCR amplification was performed using a $50-\mu \mathrm{L}$ reaction solution containing $4.0 \mu \mathrm{L}$ of dNTP $(2.5 \mathrm{mM}$ each), 5.0 $\mu \mathrm{L}$ of Buffer, $3.5 \mu \mathrm{L}$ of Ex Taq Polymerase (Takara Bio Inc., Shiga, Japan), $10 \mathrm{mM}$ each primer, and $1.0 \mu \mathrm{L}$ of extracted DNA. PCR was performed using the PC-320 Thermal Cycler (ASTEC, Fukuoka, Japan) as follows: 30 
cycles of $94{ }^{\circ} \mathrm{C}$ for $30 \mathrm{~s}, 26^{\circ} \mathrm{C}$ for $1 \mathrm{~min}$, and $47^{\circ} \mathrm{C}$ for 1 min, and a final extension at $47^{\circ} \mathrm{C}$ for $5 \mathrm{~min}$.

\section{Internal standards}

Two types of reference DNA were prepared as TGGE internal standards [35]. For reference 1 (Ref1), PCR amplification was performed using a $50-\mu \mathrm{L}$ reaction solution containing $2.0 \mu \mathrm{L}$ of M13 phage DNA (TaKaRa Bio, Inc.), $3.0 \mu \mathrm{L}$ each of $10 \mu \mathrm{M}$ MA1 (5' -TGCTACGTCTCTTCCGATGCTGTCTTTC-3') and MA2 (5'-CCTTGAATTCTATCGGTTTATCA-3'), $4.0 \mu \mathrm{L}$ of dNTP (2.5 mM each), $5.0 \mu \mathrm{L}$ of $10 \times$ Buffer, $0.15 \mu \mathrm{L}$ of Ex Taq Polymerase (Takara Bio Inc.), $10 \mathrm{mM}$ primers, and $1.0 \mu \mathrm{L}$ of extracted DNA. PCR conditions were 30 cycles of $94{ }^{\circ} \mathrm{C}$ for $30 \mathrm{~s}, 63^{\circ} \mathrm{C}$ for $1 \mathrm{~min}$, and $72^{\circ} \mathrm{C}$ for $30 \mathrm{~s}$, and a final extension at $72{ }^{\circ} \mathrm{C}$ for $5 \mathrm{~min}$.

For reference 2 (Ref2), PCR amplification was performed using a $50-\mu \mathrm{L}$ reaction solution containing $2.0 \mu \mathrm{L}$ of $\mathrm{M} 13$ phage DNA (TaKaRa Bio, Inc.), $3.5 \mu \mathrm{L}$ each of $10 \mu \mathrm{M}$ Ref6F (5' -GCCGGCATCACCGGCGCCACAGGTGCG GTTG-3') and Ref6R (5'-TAGCGAGGTGCCGCCGG CTTCCATTCAGGTC-3'), $4.0 \mu \mathrm{L}$ of dNTP $(2.5 \mathrm{mM}$ each), $5.0 \mu \mathrm{L}$ of $10 \times$ Buffer, $0.25 \mu \mathrm{L}$ of Ex Taq Polymerase (Takara Bio Inc.), $10 \mathrm{mM}$ primers, and $1.0 \mu \mathrm{L}$ of extracted DNA. PCR conditions were 30 cycles of $94{ }^{\circ} \mathrm{C}$ for $15 \mathrm{~s}, 44{ }^{\circ} \mathrm{C}$ for $30 \mathrm{~s}$, and $72{ }^{\circ} \mathrm{C}$ for $1 \mathrm{~min}$, and a final extension at $72{ }^{\circ} \mathrm{C}$ for $30 \mathrm{~s}$.

\section{Temperature gradient gel electrophoresis (TGGE)}

A total of $1.0 \mu \mathrm{L}$ of reference DNA solution was obtained by mixing the reaction solutions of Ref1 and Ref2 at a ratio of $1: 1$ and $1.0 \mu \mathrm{L}$ of the PCR solution, followed by electrophoresis. The mixed sample was applied to a $6 \%$ polyacrylamide gel and electrophoresed at $100 \mathrm{~V}$ for $10 \mathrm{~min}$ with a temperature gradient of $15^{\circ} \mathrm{C}$ to $65^{\circ} \mathrm{C}$ [36, 37]. After electrophoresis, the gel was

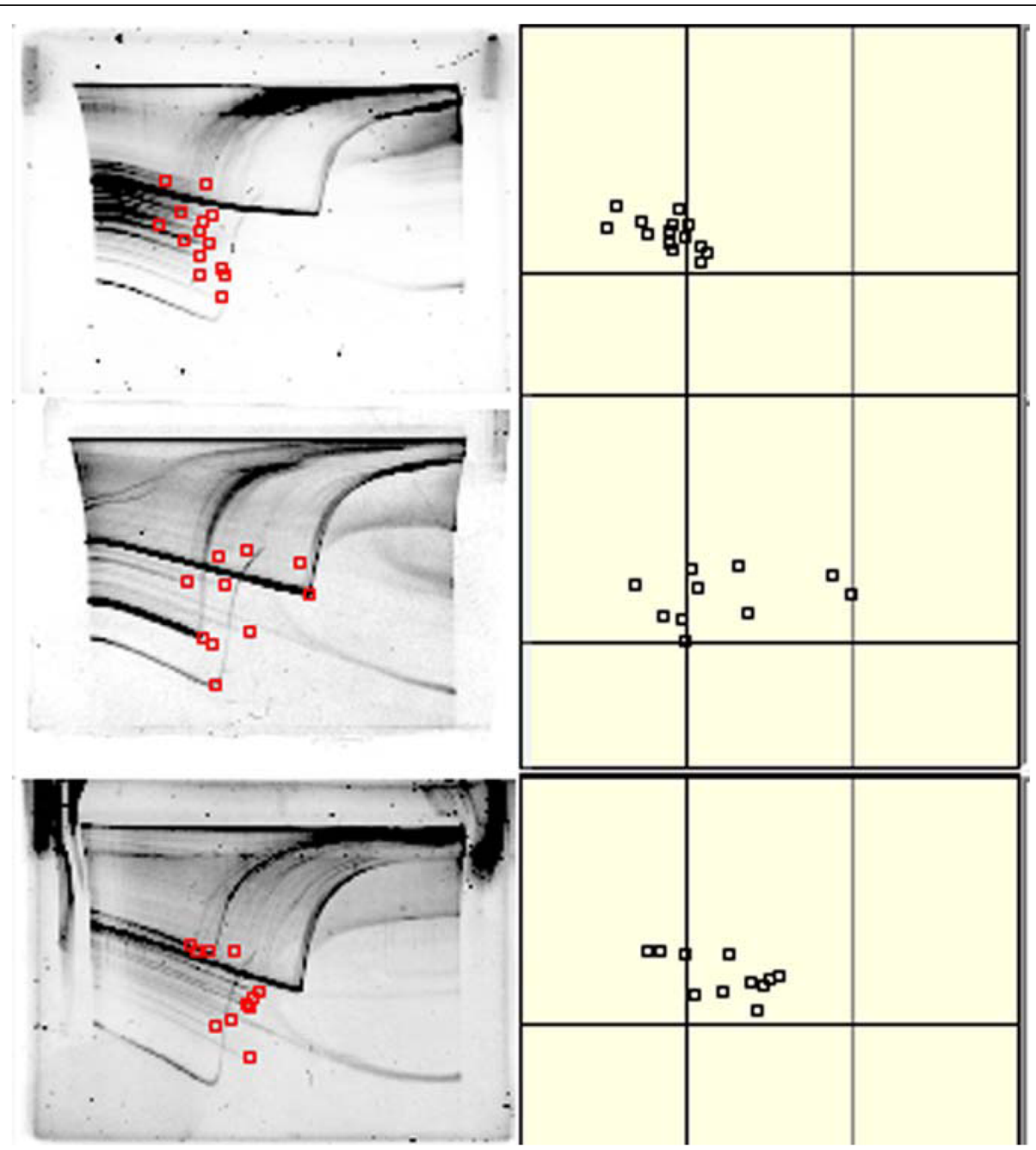

Fig. 3 Representative images of electrophoresed gels. Human, horse mackerel, and cat sample images are shown. The electrophoresed gel image is shown on the left side, and the corrected figure is shown in the right side 
stained with 0.05\% GelRed (Biotium Inc., Fremont, CA, USA) and images were obtained using the LAS 4000 Mini (FUJIFILM, Tokyo, Japan).

\section{Cluster analysis}

From the images of the electrophoresed gels, the melting points of amplified double-stranded DNA (species identification dots: spiddos) were manually plotted. The spiddos were corrected by two reference DNA spiddos. Representative images of the electrophoresed gels and corrected figures are shown in Fig. 3.

The spiddo patterns of the samples were compared, and PaSS was calculated according to the following formula using micro-TGGE Analyzer [38-42]:

$$
\text { PaSS }=1-\frac{1}{\mathrm{n}} \sum_{\mathrm{i}=1}^{\mathrm{n}} \frac{\left|\overrightarrow{P_{i}^{(1)}}-\overrightarrow{P_{i}^{(2)}}\right|}{\left|\overrightarrow{P_{i}^{(1)}}\right|+\left|\overrightarrow{P_{i}^{(2)}}\right|} \quad(\vec{P}=(\theta, \mu))
$$

PaSS takes a value of 0 to 1 , where 1 indicates a perfect match. This PaSS value was analyzed using the Ward method to create a phylogenetic tree [43].

\section{Additional files}
Additional file 1: PaSS values (SP-1). (CSV $18 \mathrm{~kb}$ )
Additional file 2: PaSS values (SP-2). (CSV $16 \mathrm{~kb}$ )
Additional file 3: PaSS values (SP-3). (CSV $18 \mathrm{~kb}$ )
Additional file 4: PaSS values (average of SP-1-3). (CSV $25 \mathrm{~kb}$ )

\section{Abbreviations}

GP: Genome profiling; PaSS: Pattern similarity score; Ref1: Reference 1; Ref2: Reference 2; STR: Short tandem repeat; TGGE: Temperature gradient gel electrophoresis

\section{Acknowledgements}

We thank Prof. Koichi Nishigaki for helpful discussion.

\section{Authors' contributions \\ TK and NI performed random PCR and temperature gradient gel electrophoresis. HT, MT, and RB analyzed the data obtained by electrophoresis. HI was a major contributor in writing the manuscript. All authors read and approved the final manuscript.}

\section{Funding}

This research, including the design of the study; collection, analysis, and interpretation of data; and writing of the manuscript, was funded by Kyoto Prefectural University of Medicine.

\section{Availability of data and materials}

All data generated or analyzed during this study are included in this published articles and its Additional files 1, 2, 3 and 4.

\section{Ethics approval and consent to participate}

This research was a part of the research project approved by an institutional review board of Kyoto Prefectural University of Medicine (G-98).

Human samples were collected from healthy adult volunteers who provided written consent.

\section{Consent for publication}

Not applicable.

\section{Competing interests}

The authors declare that they have no competing interests.

Received: 11 September 2018 Accepted: 29 May 2019

Published online: 10 June 2019

\section{References}

1. Waye JS, Presley LA, Budowle B, Shutler GG, Fourney RM. A simple and sensitive method for quantifying human genomic DNA in forensic specimen extracts. Biotechniques. 1989;7:852-5.

2. Waye JS, Michaud D, Bowen JH, Fourney RM. Sensitive and specific quantification of human genomic deoxyribonucleic acid (DNA) in forensic science specimens: casework examples. J Forensic Sci. 1991;36:1198-203.

3. Soejima M, Hiroshige K, Yoshimoto J, Koda Y. Selective quantification of human DNA by real-time PCR of FOXP2. Forensic Sci Int Genet. 2012;6:447-51.

4. $\mathrm{Ng} J$, Satkoski J, Premasuthan A, Kanthaswamy S. A nuclear DNA-based species determination and DNA quantification assay for common poultry species. J Food Sci Technol. 2014;51:4060-5.

5. Karabasanavar NS, Singh SP, Kumar D, Shebannavar SN. Detection of pork adulteration by highly-specific PCR assay of mitochondrial D-loop. Food Chem. 2014;145:530-4.

6. Wan $\mathrm{QH}$, Fang SG. Application of species-specific polymerase chain reaction in the forensic identification of tiger species. Forensic Sci Int. 2003;131:75-8.

7. Angleby H, Savolainen P. Forensic informativity of domestic dog mtDNA control region sequences. Forensic Sci Int. 2005;154:99-110.

8. Kyle CJ, Wilson CC. Mitochondrial DNA identification of game and harvested freshwater fish species. Forensic Sci Int. 2007;166:68-76 Erratum in: Forensic Sci Int. 2008;180:59.

9. Kitano T, Umetsu K, Tian W, Osawa M. Two universal primer sets for species identification among vertebrates. Int J Legal Med. 2007;121:423-7.

10. Cawthorn DM, Steinman HA, Witthuhn RC. Evaluation of the 165 and 125 rRNA genes as universal markers for the identification of commercial fish species in South Africa. Gene. 2012;491:40-8.

11. Parson W, Pegoraro K, Niederstätter H, Föger M, Steinlechner M. Species identification by means of the cytochrome b gene. Int J Legal Med. 2000; 114:23-8.

12. Thanakiatkrai $P$, Kitpipit T. Meat species identification by two direct-triplex realtime PCR assays using low resolution melting. Food Chem. 2017;233:144-50.

13. Wells JD, Wall R, Stevens JR. Phylogenetic analysis of forensically important Lucilia flies based on cytochrome oxidase I sequence: a cautionary tale for forensic species determination. Int J Legal Med. 2007;121:229-33.

14. Tobe SS, Kitchener AC, Linacre AM. Reconstructing mammalian phylogenies: a detailed comparison of the cytochrome $b$ and cytochrome oxidase subunit I mitochondrial genes. PLoS One. 2010;5:e14156.

15. Ono T, Miyaishi S, Yamamoto Y, Yoshitome K, Ishikawa T, Ishizu H. Human identification from forensic materials by amplification of a human-specific sequence in the myoglobin gene. Acta Med Okayama. 2001;55:175-84.

16. Sullivan KM, Hopgood R, Gill P. Identification of human remains by amplification and automated sequencing of mitochondrial DNA. Int J Legal Med. 1992;105:83-6.

17. Wilson MR, DiZinno JA, Polanskey D, Replogle J, Budowle B. Validation of mitochondrial DNA sequencing for forensic casework analysis. Int J Legal Med. 1995;108:68-74.

18. Parson W, Parsons TJ, Scheithauer R, Holland MM. Population data for 101 Austrian Caucasian mitochondrial DNA d-loop sequences: application of mtDNA sequence analysis to a forensic case. Int J Legal Med. 1998;111:124-32.

19. Wittig H, Augustin C, Baasner A, Bulnheim U, Dimo-Simonin N, Edelmann J, et al. Mitochondrial DNA in the Central European population. Human identification with the help of the forensic mt-DNA D-loop-base database. Forensic Sci Int. 2000;113:113-8.

20. Nakamura H, Muro T, Imamura S, Yuasa I. Forensic species identification based on size variation of mitochondrial DNA hypervariable regions. Int J Legal Med. 2009;123:177-84.

21. Nishigaki K, Amano N. Takasaka T. DNA profiling. An approach of systemic characterization, classification, and comparison of genomic DNAs. Chem Lett. 1991;20:1097-100.

22. Takasaka T, Sakurada K, Akutsu T, Nishigaki K, Ikegaya H. Trials of the detection of semen and vaginal fluid RNA using the genome profiling method. Leg Med (Tokyo). 2011;13:265-7. 
23. Hirata R, Takasaka T, Miyamori D, Ahmed S, Sakurada K, Nishigaki K, et al. Use of the genome profiling method for the identification of saliva and sweat samples. Jpn J Forensic Sci Technol. 2013;18:79-83.

24. Tanaka Y, Hirata R, Mashita K, Mclean S, Ikegaya H. Detection of human polyomavirus DNA using the genome profiling method. Open Virol J. 2015;9:29-37.

25. Suwa N, Ikegaya H, Takasaka T, Nishigaki K, Sakurada K. Human blood identification using the genome profiling method. Leg Med (Tokyo). 2012; 14:121-5.

26. Futakami M, Salimullah M, Miura T, Tokita S, Nishigaki K. Novel mutation assay with high sensitivity based on direct measurement of genomic DNA alterations: comparable results to the Ames test. J Biochem. 2007;141:675-86.

27. Suwa N, Ishikawa N, Miyamori D, Ikegaya $H$. The GP method can be effective as a screening test before STR typing. Int J Hum Genet. 2018; 18:22-7.

28. Dumache R, Ciocan V, Muresan C, Enache A. Molecular DNA analysis in forensic identification. Clin Lab. 2016;62:245-8.

29. Butler JM, Buel E, Crivellente F, McCord BR. Forensic DNA typing by capillary electrophoresis using the ABI Prism 310 and 3100 genetic analyzers for STR analysis. Electrophoresis. 2004;25:1397-412.

30. Srivastava S, Avvaru AK, Sowpati DT, Mishra RK. Patterns of microsatellite distribution across eukaryotic genomes. BMC Genomics. 2019;20:153.

31. Kouduka M, Sato D, Komori M, Kikuchi M, Miyamoto K, Kosaku A, et al. A solution for universal classification of species based on genomic DNA. Int J Plant Genomics. 2007;2007:27894.

32. Yamamoto M, Ishii A, Nogi Y, Inoue A, Ito M. Isolation and characterization of novel denitrifying alkalithermophiles, AT-1 and AT-2. Extremophiles. 2006; 10:421-6.

33. Hamano K, Ueno-Tsuji S, Tanaka R, Suzuki M, Nishimura K, Nishigaki K. Genome profiling (GP) as an effective tool for monitoring culture collections: a case study with Trichosporon. J Microbiol Methods. 2012;89: $119-28$.

34. Sakuma Y, Nishigaki K. Computer prediction of general PCR products based on dynamical solution structures of DNA. J Biochem. 1994;116:736-41.

35. Nishigaki K, Naimuddin M, Hamano K. Genome profiling: a realistic solution for genotype-based identification of species. J Biochem. 2000;128:107-12.

36. Nishigaki K, Miura T, Tsubota M, Sutoh A, Amano N, Husimi Y. Structural analysis of nucleic acids by precise denaturing gradient gel electrophoresis: II. Applications to the analysis of subtle and drastic mobility changes of oligo- and polynucleotides. J Biochem. 1992;111:151-6.

37. Biyani M, Nishigaki K. Sequence-specific and nonspecific mobilities of singlestranded oligonucleotides observed by changing the borate buffer concentration. Electrophoresis. 2003;24:628-33.

38. Nishigaki K, Husimi Y, Masuda M, Kaneko K, Tanaka T. Strand dissociation and cooperative melting of double-stranded DNAs detected by denaturant gradient gel electrophoresis. J Biochem. 1984;95:627-35.

39. Naimuddin M, Kurazono T, Nishigaki K. Commonly conserved genetic fragments revealed by genome profiling can serve as tracers of evolution. Nucleic Acids Res. 2002;30:e42.

40. Biyani M, Nishigaki K. Structural characterization of ultra-stable higherordered aggregates generated by novel guanine-rich DNA sequences. Gene. 2005;364:130-8.

41. Naimuddin M, Kurazono T, Zhang Y, Watanabe T, Yamaguchi M, Nishigaki K. Species-identification dots: a potent tool for developing genome microbiology. Gene. 2000;261:243-50.

42. Kouduka M, Matuoka A, Nishigaki K. Acquisition of genome information from single-celled unculturable organisms (radiolaria) by exploiting genome profiling (GP). BMC Genomics. 2006;7:135.

43. Ward JH Jr. Hierarchical grouping to optimize an objective function. J Am Stat Assoc. 1963;58:23-8.

\section{Publisher's Note}

Springer Nature remains neutral with regard to jurisdictional claims in published maps and institutional affiliations.

\section{Ready to submit your research? Choose BMC and benefit from:}

- fast, convenient online submission

- thorough peer review by experienced researchers in your field

- rapid publication on acceptance

- support for research data, including large and complex data types

- gold Open Access which fosters wider collaboration and increased citations

- maximum visibility for your research: over $100 \mathrm{M}$ website views per year

At $\mathrm{BMC}$, research is always in progress.

Learn more biomedcentral.com/submissions 